\title{
Removal of Solids from Palm Oil Mill Effluent and Paint Wastewater Using Electrocoagulation Technique
}

\author{
Joseph Tagbo Nwabanne, Ozioma Onyinye Oguegbu (D), and Chinedu Matthew Agu \\ Department of Chemical Engineering, Nnamdi Azikiwe University, Awka, Nigeria \\ Correspondence should be addressed to Ozioma Onyinye Oguegbu; oziomaonyinye@gmail.com
}

Received 25 May 2018; Revised 1 October 2018; Accepted 9 October 2018; Published 1 November 2018

Academic Editor: Adalgisa Rodrigues de Andrade

Copyright (C) 2018 Joseph Tagbo Nwabanne et al. This is an open access article distributed under the Creative Commons Attribution License, which permits unrestricted use, distribution, and reproduction in any medium, provided the original work is properly cited.

\begin{abstract}
Electrocoagulation has been employed as a treatment technique for treating various wastewaters. This study focuses on the performance of electrocoagulation process for the treatment of Palm Oil Mill Effluent (POME) and Paint Wastewater (PW) using iron electrodes. POME obtained from local palm oil producers and PW from a paint industry, both in Enugu state of Nigeria, were treated by electrocoagulation using two iron electrodes. Effects of current density, electrocoagulation time, $\mathrm{pH}$, and temperature were studied. Results revealed that this process could reduce the concentration of Total Suspended and Dissolved Solids (TSDP), in both POME and PW. The highest removal efficiencies of $65 \%$ and $76 \%$ were obtained for POME and PW, respectively, at 3 Amps, $60 \mathrm{~min}, \mathrm{pH}$ of 10 , and $50^{\circ} \mathrm{C}$ for POME and $3 \mathrm{Amps}, 60 \mathrm{~min}, \mathrm{pH}$ of 6 , and $60^{\circ} \mathrm{C}$ for PW. Of the two kinetic models studied, second-order kinetic model fitted best to the obtained experimental kinetic data. From this study, it can be concluded that electrocoagulation is effective in the treatment of POME and PW.
\end{abstract}

\section{Introduction}

Environmental pollution has been an issue of serious concern in the world. This is attributed to its effect on the quality and hence deterioration in water quality as well as other parts of the environment as a result of the alteration of the natural standard due to pollution [1].

Increased human activities such as industrialization have led so much to the current level of pollution. Dangerous conditions like Ozone depletion, green-house effect, and global warming have resulted from the release of toxic gaseous substances into the atmosphere [2]. Also, the indiscriminate releases of wastewaters into the environment have adversely affected the soil quality, water bodies, and the entire ecosystem [3].

With rapid industrialization in the world today, huge amount of water is used as raw material, for washing purpose, as well as for cooling of equipment. As such, several raw material, intermediate products, and wastes are brought into water during industrial processes [4]. In other words, wastewater is a major pollutant source into the environment.

Contaminants from industrial wastewaters vary from industry to industry. However, on a general note, they basically consist of high chemical oxygen demand (COD), suspended and dissolved solids, biological oxygen demand, oil, color, metals, acids, salts, and organic chemicals $[5,6]$. Because of the negative impact of these contaminants on the environment, the treatment of industrial waste water becomes very important. This is due to the considerable damage on the environment by these contaminants [7]. In other words, there is need to treat the waste water prior to its discharge to the environment.

Wastewaters can be treated by a number of methods. Some of these methods include but not limited to precipitation, coagulation, flocculation, adsorption, filtration, flotation, ion exchange, reverse osmosis, chlorination, ozonation, electrocoagulation, etc. Chemical substances are commonly used for industrial wastewater treatment for the removal of the targeted pollutants. Some of these substances includes precipitate, lime, soda ash, sodium sulfide, hydrogen sulfide, phosphoric acid, ferric sulphate, ferric chloride, alum, sodium sulphate, carbamates, etc. [8].

However, for the purpose of this present study, electrocoagulation was used for the treatment of Palm Oil Mill Effluent and paint wastewater. Electrocoagulation is an efficient treatment method for wastewaters treatment. This is 
because it efficiently removes turbidity and decreases the level of suspended solids [1,9]. Electrocoagulation also known as radio frequency diathermy or short wave electrolysis is a technique used for wash water treatment, wastewater treatment, industrial processed water, and medical treatment [5]. The major advantages of electrocoagulation over other conventional techniques, such as chemical coagulation and adsorption, are "in situ" delivery of reactive agents, no generation of secondary pollution, and compact nature of the equipment [10]. Electricity-based electrocoagulation technology removes contaminants that are impossible to be removed by filtration or other chemical treatment methods. Some of such contaminants include oil, total petroleum hydrocarbons, suspended solids, and heavy metals [3, 11].

In other to ensure effective and efficient electrocoagulation treatment of wastewater, there is need for the study of the kinetic of the treatment process. A number of studies have been conducted on the kinetics of electrocoagulation process $[5,12]$. The results of the studies indicate that the kinetics of electrocoagulation process is highly dependent on the current density, time, $\mathrm{pH}$, and temperature [13].

However, there is limited and diffuse information on how these parameters (current density, time, $\mathrm{pH}$, and temperature) affect electrocoagulation of Palm Oil Mill Effluent (POME) and Paint Wastewater (PW) using only iron electrode. Although Chantaraporn [14] studied the pretreatment of POME by electrocoagulation, the treatment was conducted using aluminum electrode. Likewise, Abdurrahman [15] studied treatment of paint wastewater using electrocoagulation method. However, combinations of aluminum and iron electrodes were used. Hence, these are motivations to study the treatment of both wastewaters, using iron electrodes.

In other words, the objectives of this study were to (1) evaluate the effects of current density, time, $\mathrm{pH}$, and temperature on turbidity removal efficiency of POME and PW using iron electrode and (2) characterize the treated wastewaters to ensure compliance with required standards. Furthermore, electrocoagulation experimental data were fitted to firstorder and second-order electrocoagulation kinetic models, so as to investigate how the process parameters related to process kinetics. Furthermore, the fitting of each model to the experimental kinetic data was estimated using correlation coefficient $\left(\mathrm{R}^{2}\right)$.

Theory of Electrocoagulation. A good number of authors have discussed the theory of electrocoagulation (EC) $[10,14]$. This process is comprised of three successive stages.

(1) Formation of coagulants by electrolytic oxidation of the sacrificial electrode, which may be summarizes as follows:

(a) Compression of the diffuse double-layer around the charged species, which is achieved by the interactions of ions generated by dissolution of the sacrificial electrode, due to passage of current through the solution.

(b) Charge neutralization of the ionic species present in wastewater. This is caused by the counterions produced by the electrochemical dissolution of the sacrificial electrode. These counterions reduce the electrostatic interparticle repulsion sufficiently so that the van der Waals attraction predominates, thus causing coagulation. A zero net charge results in the process.

(c) Floc formation: the floc formed as a result of coagulation creates a sludge blanket that entraps and bridges colloidal particles.

(2) Destabilization of the contaminants, particulate suspension, and breaking of emulsion.

(3) Aggregation of the destabilized phases to form flocs.

The chemistry of the aqueous medium is very essential is electrocoagulation studies. When charge is applied from an external source, the anode is oxidized while the cathode undergoes reduction. Often, aluminum and iron are used as electrodes during this process. However, this study was centered on the use of only iron electrodes. The following are the two proposed reaction mechanisms:

\section{First Mechanism:}

$$
\begin{aligned}
& \text { Anode: } 4 \mathrm{Fe}(\mathrm{s}) \longrightarrow 4 \mathrm{Fe}+2(\mathrm{aq})+8 \mathrm{e} \\
& 4 \mathrm{Fe}+2(\mathrm{aq})+10 \mathrm{H}_{2} \mathrm{O}(\mathrm{l})+\mathrm{O}_{2}(\mathrm{~g}) \longrightarrow \\
& 4 \mathrm{Fe}(\mathrm{OH})_{3}(\mathrm{~s})+8 \mathrm{H}+(\mathrm{aq}) \\
& \text { Cathode: } 8 \mathrm{H}+(\mathrm{aq})+8 \mathrm{e} \longrightarrow 4 \mathrm{H}_{2}(\mathrm{~g}) \\
& \text { Overall: } 4 \mathrm{Fe}(\mathrm{s})+10 \mathrm{H}_{2} \mathrm{O}(\mathrm{l})+\mathrm{O}_{2}(\mathrm{~g}) \longrightarrow \\
& 4 \mathrm{Fe}(\mathrm{OH})_{3}(\mathrm{~s})+4 \mathrm{H}_{2}(\mathrm{~g})
\end{aligned}
$$

Second Mechanism:

$$
\begin{gathered}
\text { Anode: } \mathrm{Fe}(\mathrm{s}) \longrightarrow \mathrm{Fe}+2(\mathrm{aq})+2 \mathrm{e}- \\
\mathrm{Fe}_{2}(\mathrm{aq})+2 \mathrm{OH}-(\mathrm{aq}) \longrightarrow \mathrm{Fe}(\mathrm{OH})_{2}(\mathrm{~s}) \\
\text { Cathode: } 2 \mathrm{H}_{2} \mathrm{O}(\mathrm{l})+2 \mathrm{e}-\longrightarrow \mathrm{H}_{2}(\mathrm{~g})+2 \mathrm{OH}-(\mathrm{aq}) \\
\text { Overall: } \mathrm{Fe}(\mathrm{s})+2 \mathrm{H}_{2} \mathrm{O}(\mathrm{l}) \longrightarrow \mathrm{Fe}(\mathrm{OH})_{2}(\mathrm{~s})+\mathrm{H} 2(\mathrm{~g})
\end{gathered}
$$

\section{Materials and Methods}

2.1. Effluent Collection and Characteristics. This study was carried out at the chemical Engineering laboratory, Nnamdi Azikiwe University Awka, Anambra State of Nigeria. Wastewaters were collected from industries in Enugu state of Nigeria. Palm Oil Mill Effluent (POME) was obtained from local palm oil producer at Adelabu Street, Uwani, Enugu, Enugu state. POME was collected from the discharge tank where all wastewaters are collected before being discharged. A clean 25 liter container was used to collect the waste water. The container was corked, sealed, and refrigerated until the commencement of the analysis.

Similarly, the paint wastewater was collected from Flourish Paint, located at Plot D, Emene Industrial Layout, Enugu State, Nigeria. PW was collected with a 20-liter container. 


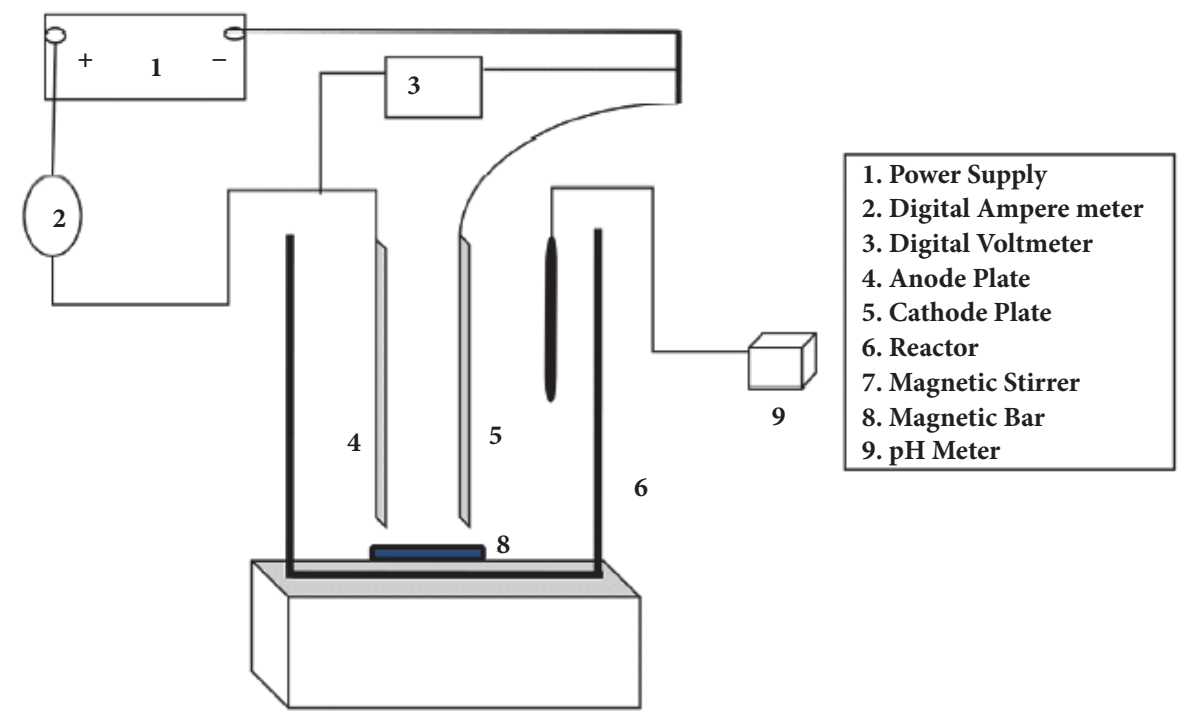

FIGURE 1: Electrocoagulation reactor.

The container cans were sealed and refrigerated until the commencement of the analysis.

The effluents were characterized to determine their physical, chemical, and microbiological characteristics prior to their treatment.

2.2. Experimental Setup. A laboratory scale electrochemical setup made up of circular cell, electrodes, and other accessories were arranged. Two iron electrodes with surface area of $32 \mathrm{~cm}^{2}$ were used. The electrolytic cell (electrocoagulator) used was a $600 \mathrm{ml}$ cylinder glass reactor with a working volume of $500 \mathrm{ml}$, equipped with a magnetic stirrer as shown in Figure 1. The stirring speed of the stirrer was set at $150 \mathrm{rpm}$.

The separation between the anode and the cathode was kept at $5.7 \mathrm{~cm}$. The solution in the reactor was stirred by a plate impeller at a rotating velocity of $150 \mathrm{rpm}$. Controlled direct current was supplied by a DC power supply. The current readings were measured with an ammeter, while the temperature measurement was taken using an electronic hot plate.

2.3. Experimental Procedure. After detailed characterization of the wastewaters, several electrocoagulation (EC) batch experiment runs were performed in the laboratory. Initially the wastewaters were rigorously stirred for few minutes using the stirrer. This was to ensure proper homogenization of the samples.

During the EC experiment, the effects of $\mathrm{pH}$, current density, time and temperature were studied. $\mathrm{H}_{2} \mathrm{SO}_{4}$ and $\mathrm{NaOH}$ were used to adjust the $\mathrm{pH}$ value of the samples. Before each run, electrodes were washed thoroughly to remove any surface grease or solid residues.

In the treatment of POME, experimental runs were conducted to determine the effects of the process parameters. This was achieved by varying $\mathrm{pH}(2,4,6$, and 8$)$ against current densities $(0.5,1.0,1.5,2.0$, and $3.0 \mathrm{~A})$ at 60 minutes and $50^{\circ} \mathrm{C}$. Subsequently, current densities $(0.5,1.0,1.5,2.0$, and $3.0 \mathrm{~A})$ were varied with time $(5,10,1520,25,30$, and 60 $\min )$ at $50^{\circ} \mathrm{C}$ and pHof6. Afterwards temperatures $(30,35,40$, 50 , and $\left.60^{\circ} \mathrm{C}\right)$ were varied against time $(5,10,1520,25,30$, and $60 \mathrm{~min})$ at $\mathrm{pH}$ of 10 and current density of $3 \mathrm{~A}$.

Similarly, for PW treatment, experiments were also carried out to determine the effects of the process parameters. This was done by varying $\mathrm{pH}(2,4,6$, and 8$)$ against current densities $(0.5,1.0,1.5,2.0$, and $3.0 \mathrm{~A})$ at 60 minutes and $60^{\circ} \mathrm{C}$. Subsequently, current densities $(0.5,1.0,1.5,2.0$, and $3.0 \mathrm{~A})$ were varied with time $(5,10,1520,25,30$, and $60 \mathrm{~min})$ at $60^{\circ} \mathrm{C}$ and $\mathrm{pH}$ of 6 . Subsequently, temperatures $(30,35,40,50$, and $\left.60^{\circ} \mathrm{C}\right)$ were varied against time $(5,10,1520,25,30$, and 60 min) at $\mathrm{pH}$ of 6 and current density of $3 \mathrm{~A}$.

In each experimental run, after proper homogenous stirring is attained, $100 \mathrm{ml}$ of supernatant sample was collected for laboratory analysis.

The removal efficiency of by EC process for the removal of total dissolved and suspended particles (TDSP) was determined using

$$
\mathrm{Qt}=\frac{\mathrm{Co}-\mathrm{Ce}}{\mathrm{Co}} \times 100
$$

It is important to state that it is recommended that, at the end of process, the residues are treated before disposal. However, due to minimal volume of sludge generated in this study, the sludge was buried without further treatment. This is because, considering the cost of sludge treatment, it would be uneconomical to treat such minimal quantity of sludge. It is generally known that sludge generation in electrocoagulation is minimal $[3,10]$.

2.4. Analysis Methods and Procedures. Analyses were carried out on the wastewaters (POME and PW). The physiochemical characterization followed standard methods. The $\mathrm{pH}$, total suspended solids, total dissolved solids, COD, BOD, total 
TABLE 1: Characterization result of POME before electrocoagulation and after electrocoagulation at optimum conditions of 3 Amps, $60 \mathrm{~min}$, $\mathrm{pH}$ of 10 , and $30^{\circ} \mathrm{C}$

\begin{tabular}{lcc}
\hline Parameter & Before electrocoagulation & After electrocoagulation \\
\hline Ph & 5.9 & 4.7 \\
Total solids (mg/l) & 37,520 & 18 \\
TSS (m) & 11,024 & 8 \\
TDS (mg/l) & 25,426 & 11 \\
Turbidity (NTU) & 1,716 & 103 \\
BOD (mg/l) & 36,667 & 26 \\
COD (mg/l) & 44,300 & 264 \\
Odour & Positive & Positive \\
Conductivity $(\mu \mathrm{s} / \mathrm{cm})$ & 1,587 & 1024 \\
Chloride $(\mathrm{mg} / \mathrm{l})$ & 618 & 243.3 \\
Sulphate $(\mathrm{mg} / \mathrm{l})$ & 934 & 523 \\
Lead $(\mathrm{mg} / \mathrm{l})$ & 0.025 & 0.001 \\
\hline
\end{tabular}

TABLE 2: Characterization result of $\mathrm{PW}$ before electrocoagulation and after electrocoagulation at optimum conditions of $3 \mathrm{Amps}, 60 \mathrm{~min}, \mathrm{pH}$ of 2 , and $60^{\circ} \mathrm{C}$.

\begin{tabular}{lcc}
\hline Parameter & Before electrocoagulation & After electrocoagulation \\
\hline $\mathrm{pH}$ & 10.1 & 7.4 \\
Total solids $(\mathrm{mg} / \mathrm{l})$ & 40,058 & 11 \\
$\mathrm{TSS}(\mathrm{m})$ & 3,821 & 3.9 \\
$\mathrm{TDS}(\mathrm{mg} / \mathrm{l})$ & 36,179 & 6.1 \\
Turbidity $(\mathrm{NTU})$ & 788 & 49 \\
$\mathrm{BOD}(\mathrm{mg} / \mathrm{l})$ & 1,866 & 3.7 \\
COD $(\mathrm{mg} / \mathrm{l})$ & 3,137 & 242 \\
Odour & Positive & Positive \\
Conductivity $(\mu \mathrm{s} / \mathrm{cm})$ & 1,769 & 1,003 \\
Chloride $(\mathrm{mg} / \mathrm{l})$ & 386 & 242.4 \\
Sulphate $(\mathrm{mg} / \mathrm{l})$ & 760 & 248 \\
Lead $(\mathrm{mg} / \mathrm{l})$ & 0.039 & 0.012 \\
\hline
\end{tabular}

solids, turbidity, electrical conductivity, chloride, sulphate, and odour were determined in accordance with the APHA standard methods [16].

\section{Results and Discussion}

\subsection{Characterization of Effluents before and after Treatment}

3.1.1. Characterization of POME before and after Electrocoagulation. Table 1 shows the characterization results of Palm Oil Mill Effluent (POME). From the results in Table 1, POME contains high quantity of solids (suspended and dissolved solids). This could be attributed to the high solid content emanating from the palm fruit $[8,17]$. The high solid content emerges from the leaching process involved in palm oil processing. As such, the palm oil mill effluents are accompanied by solids and are carried along with water during processing. In other words, electrocoagulation treatment helps to achieve reasonable reduction in the solids (both suspended and dissolved) in POME [14]. The high value of TDS or electrical conductivity is advantageous to wastewater treatment using EC method. This is because it will eliminate the need to add an electrolyte needed to facilitate the passage of current in the wastewater solution. Also, the presence of chloride at relatively high concentrations helps in the production of chlorine as a result of the electrochemical process [10]. This is because since chlorine is an oxidizing agent, it participates in oxidizing soluble ferrous ions into insoluble ferric ions [18]. Although POME exhibits high BOD and COD; however, electrocoagulation treatment method was effective in reducing dissolved organic substances. This was evident in the reduction in $\mathrm{BOD}$ and $\mathrm{COD}$ after the treatment [19].

3.1.2. Characterization of $P W$ before and after Electrocoagulation. Table 2 shows the characterization result of paint wastewater (PW). Like in the case of POME, the obtained result shows that $\mathrm{PW}$ is also high in suspended and dissolved solids. It is also high in BOD and COD [20]. The turbidity, total dissolved solids (TDS), and total suspended solids (TSS) were also reasonably reduced after the treatment [15]. This could be attributed to the collision of particles [15]. The high values of TDS and electrical conductivity contributed immensely to the efficiency of EC treatment [10]. The $\mathrm{pH}$ 


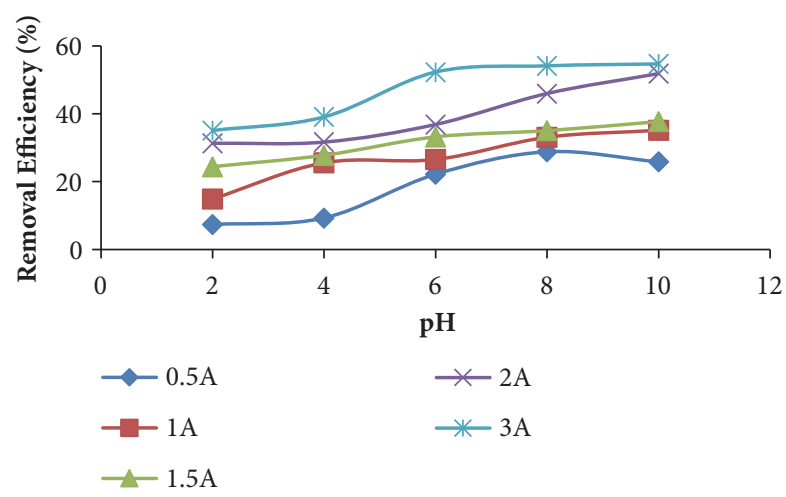

FIGURE 2: Effect of $\mathrm{pH}$ at varying current densities, for POME at $50^{\circ} \mathrm{C}$.

of the wastewater before and after treatment was 10 and 7 , respectively. The alkaline nature of the wastewater was instrumental to the effective removal of COD and turbidity. This was similar to the result obtained by Kobya [21] for removal of COD and turbidity from textile mill effluents. However, in their work, at $\mathrm{pH} 10$, they found highest removal of COD and turbidity. This characterization result also revealed that a reduction in the quantity of lead was also achieved which would be accounted to the initial $\mathrm{pH}$ of the wastewater before electrocoagulation. Shakir and Husein [22] also found an initial $\mathrm{pH}$ of 10 to be more suitable for the removal of lead by electrocoagulation.

\subsection{Effect of Operating Parameters}

3.2.1. Effect of $\mathrm{pH}$ on Electrocoagulation Process. Figures 2 and 3 show the effect of $\mathrm{pH}$ on the removal efficiency for POME and PW, respectively. The performance of electrocoagulation process is highly dependent on the $\mathrm{pH}$ of the solution. The effect of $\mathrm{pH}$ on electrocoagulation of POME and $\mathrm{PW}$ was studied within the $\mathrm{pH}$ range of $2-10$, at $50^{\circ} \mathrm{C}$ and $60^{\circ} \mathrm{C}$ for POME and $\mathrm{PW}$, respectively, with varying current densities. Figure 2 shows that the removal efficiency increased significantly when the solution $\mathrm{pH}$ was increased to 10, for POME. This could be attributed to the fact that increasing the solution $\mathrm{pH}$ can destroy the passive iron oxide layer that is formed at lower $\mathrm{pH}$. The obtained results were similar to that obtained by Nur and Zawawi [23] for the electrocoagulation of POME using aluminum electrodes. They reported that an increase in the $\mathrm{pH}$ of the solution leads to a concurrent increase in the removal efficiency. In most case, $\mathrm{pH}$ increases during an electrochemical process. This is due to the fact that the process leads to the formation of metallic oxide [14]. These generated metallic ions undergo further spontaneous reactions to produce their respective corresponding hydroxides. In this study, iron hydroxide is produced.

Figure 3 shows the electrocoagulation treatment of PW. In this figure, it is evident that an increase in $\mathrm{pH}$ beyond 6 resulted in decreased removal efficiency. However, it is important to note that the highest removal efficiency was

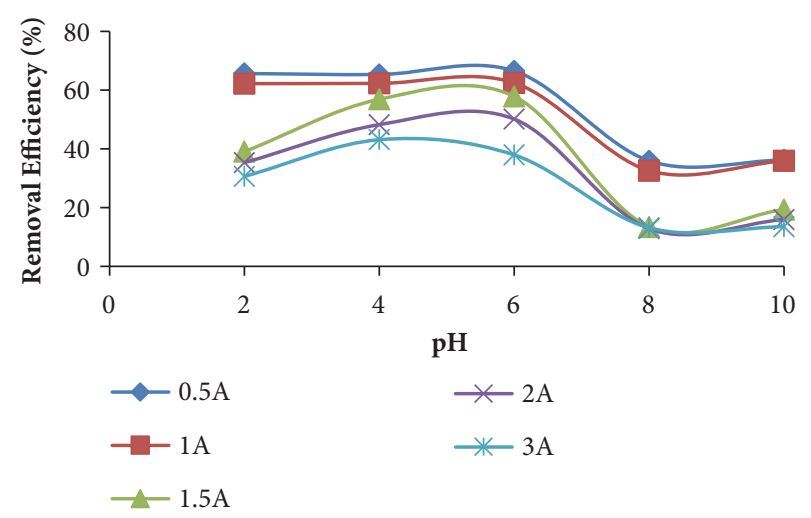

Figure 3: Effect of $\mathrm{pH}$ at varying current densities, for $\mathrm{PW}$ at $60^{\circ} \mathrm{C}$.

attained at $\mathrm{pH}$ of 6 . The high percentage of pollutant removal at this acidic medium was attributed to hydrogen evolution and the generation of $\mathrm{OH}$ - ions at the cathodes. Hence, acidic $\mathrm{pH}$ favored PW treatment using EC. The obtained result was similar to the results obtained by Abdurrahman [15], for the treatment of paint wastewater by electrocoagulation. He stated that the removal efficiency increased significantly from $\mathrm{pH} 2-4$, though beyond which no much increment was recorded. However, in this study, the slight increase in the removal efficiency as the $\mathrm{pH}$ was further increased to 6 could be attributed to the variation in the types of paint from which the wastewaters were generated.

Figures 2 and 3 showed a contrast in response of the effluents (POME and PW) to acidity and alkalinity. Alkalinity was found to favor removal of pollutants in POME, while acidity favored pollutant removal in PW. This variation is attributed to the evolution of hydrogen and $\mathrm{OH}$ - ions at the cathode, which was favored by alkalinity in POME and inhibited by the acidity of PW. In other words, the effect of operating parameters in a water treatment depends a lot on the type of wastewater. This is attributed to the fact that the composition of an effluent affects its behavior. Hence, the behavioral contradiction as evident in the POME and PW treatment is studied.

After the EC process, the effluents were observed to have an increase in the value of their $\mathrm{pH}$ compared to their initial $\mathrm{pH}$, due to the generation of $\mathrm{OH}$ ion in the EC process [23]. This is described by

$$
\begin{gathered}
\mathrm{Fe}(\mathrm{s}) \\
3 \mathrm{Fe}^{+3}{ }_{\mathrm{aq}}+3 \mathrm{e}^{-} \text {(anode) } \\
3 \mathrm{H}_{2} \mathrm{O}+3 \mathrm{e}^{-} \longleftrightarrow \frac{3}{2} \mathrm{H}_{2 \mathrm{~g}}+3 \mathrm{OH}^{-} \text {aq }(\text { cathode })
\end{gathered}
$$

In addition, $\mathrm{Fe}^{3+}$ and $\mathrm{OH}^{-}$ions generated at electrode surfaces react in the bulk wastewater to form ferric hydroxide:

$$
\mathrm{Fe}^{+3}{ }_{\mathrm{aq}}+3 \mathrm{OH}^{-}{ }_{\mathrm{aq}} \longleftrightarrow \mathrm{Fe}(\mathrm{OH})_{3}
$$

3.2.2. Effect of Settling Time and Current Density on Electrocoagulation Process. Figure 5 shows the effect of current density and settling time on the removal efficiency during 


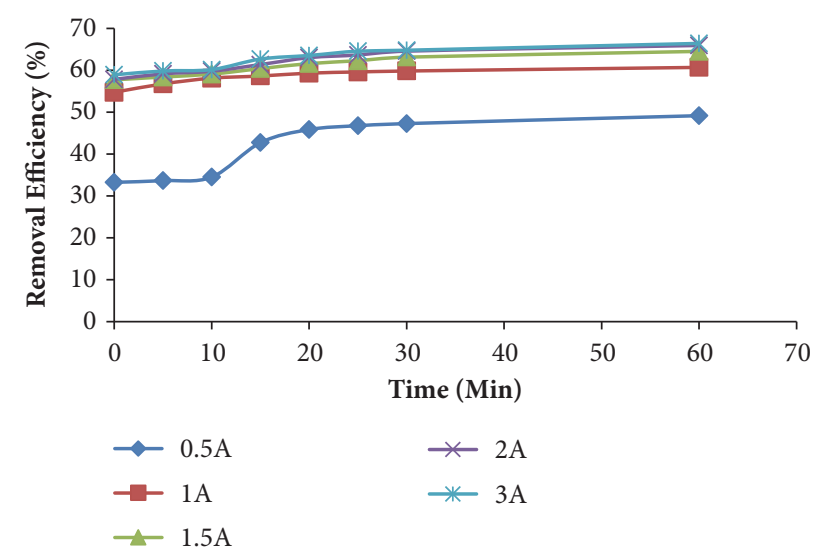

Figure 4: Effect of time and current densities, for POME at $30^{\circ} \mathrm{C}$ and $\mathrm{pH}$ of 10 .

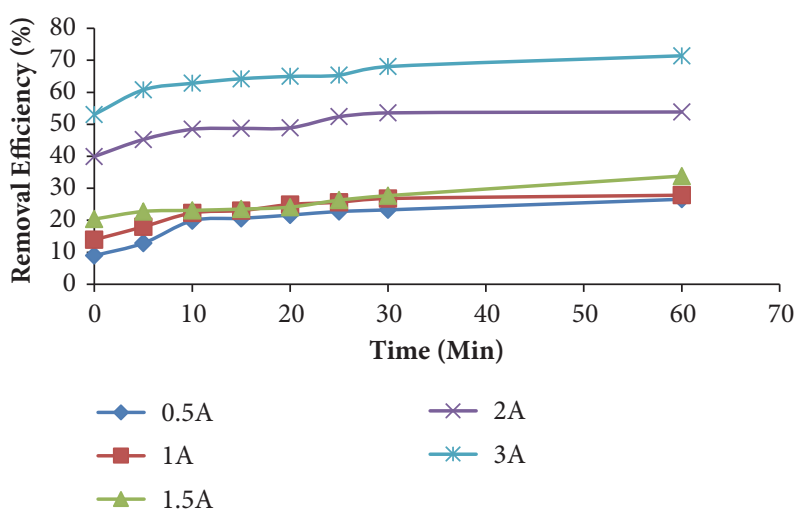

Figure 5: Effect of time and current densities, for PW at $30^{\circ} \mathrm{C}$ and $\mathrm{pH}$ of 6 .

electrocoagulation treatment of paint wastewater. Current density and time have significant effect on the treatment efficiency using electrochemical process [24]. These parameters were examined to determine the optimum level. The current density ranged from 0.5 to $3 \mathrm{~A}$.

To determine the effect of current density and settling time, the experiment was performed at optimum temperatures of $50^{\circ} \mathrm{C}$ and $60^{\circ} \mathrm{C}$ for POME and PW, respectively. During electrocoagulation process, significant quantity of dissolved and suspended solids is removed in the first 510 minutes of stirring, before settling commences. For this reason, there was already some removal from settling time 0min. After stirring, the water sample is allowed to settle for further solid removal to occur. Hence, there is need to study the effect of settling time.

Removal efficiency of about $66 \%$ was achieved in POME at the current density of $3 \mathrm{~A}$ and time $60 \mathrm{mins}$ as shown in Figure 4. This shows that high current density resulted in high removal efficiency in POME. The steadiness of removal efficiency in POME at 1.5-3A corresponds to steadiness in the generation of bubbles observed during electrocoagulation of POME. This result is in agreement with the findings of

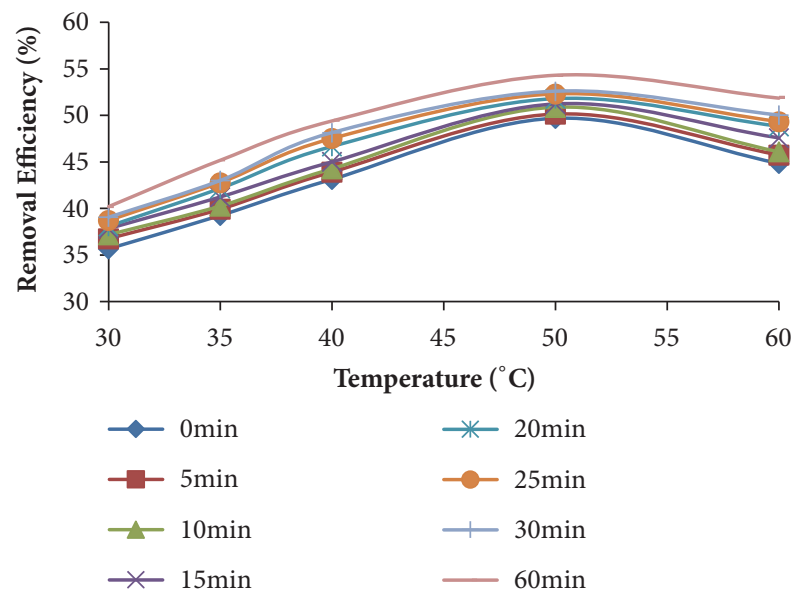

FIGURE 6: Effect of temperature, at varying time for POME at current density of $3 \mathrm{~A}$ and $\mathrm{pH}$ of 10 .

Chantaraporn [14] and Yaakob [25] who reported that moderately high current density results in high removal efficiency in POME.

71\% TSDP removal was achieved in PW at current density of $3 \mathrm{~A}$ and time of 60 mins. This shows that high current density and time resulted in increased removal efficiency in PW (Figure 5). The removal efficiency in PW increased from 0-25 minutes settling time. After 25 mins, no increase in the removal efficiency was noticed. This is attributed to decreased cathodic reaction. The trend of electrocoagulation efficiency experienced in PW is similar to the observation of Abdurrahman [15] in the treatment of paint manufacturing wastewater.

3.2.3. Effect of Temperature on Electrocoagulation. Figures 6 and 7 depict the effect of solution temperature on the electrocoagulation performance. The result shows that removal of suspended and dissolved particles from POME increased when the solution temperature increased to $50^{\circ} \mathrm{C}$. However, with further increase in the solution temperature there was decrease in the removal efficiency. This could be attributed to the fact that increasing solution temperature improves ion transfer from the anode and/or cathode surface to the solution and in other words leads to in decrease in solution viscosity and consequent increase in the ion diffusivity according to Stocks equation of diffusivity. Similar result was reported by El-Shazly and Danous [5] in the removal of phosphate ion from industrial effluent. They reported that removal efficiency of phosphate ion was increased by increasing the solution temperature up to $60 \%$. They also reported that a further increase in the solution temperature was found to decrease the removal efficiency of the phosphate ion. Furthermore, Figure 7 shows that removal of TSDP from $\mathrm{PW}$ increased by increasing solution temperature to $60^{\circ} \mathrm{C}$.

\subsection{Electrocoagulation Kinetics}

3.3.1. First-Order Kinetics. Equation (13) is the first-order kinetic equation. Equation (15) is the linearized form of (13). 
TABLE 3: First-order kinetics parameters for POME and PW.

\begin{tabular}{lcccccc}
\hline & \multicolumn{2}{c}{ POME } & \multicolumn{2}{c}{ PW } \\
\hline Current density (A) & Reaction constant (K) & $\mathrm{R}^{2}$ & Ln Co & Reaction constant (K) & $\mathrm{R}^{2}$ & Ln Co \\
0.5 & 0.0113 & 0.9476 & 7.9448 & 0.0079 & 0.9752 & 8.2247 \\
1.0 & 0.0051 & 0.9344 & 7.518 & 0.0067 & 0.9356 \\
1.5 & 0.0048 & 0.9733 & 7.4686 & 0.001 & 0.9697 \\
2.0 & 0.0064 & 0.9743 & 7.4639 & 0.0061 & 8.084 \\
3.0 & 0.0062 & 0.9307 & 7.4423 & 0.0096 & 0.9366 \\
\hline
\end{tabular}

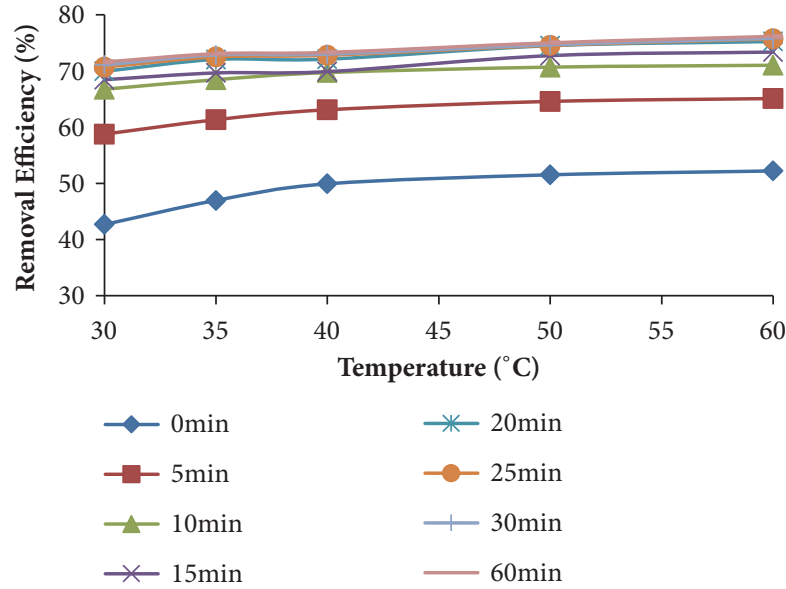

Figure 7: Effect of temperature, at varying time for PW at current density of $3 \mathrm{~A}$ and $\mathrm{pH}$ of 6 .

$$
\begin{aligned}
-\frac{\mathrm{dC}}{\mathrm{dt}} & =\mathrm{KC} \\
\frac{\mathrm{dC}}{\mathrm{C}} & =-\mathrm{Kdt}
\end{aligned}
$$

Upon integration, we have

$$
\ln \lfloor C\rfloor=-K t+\ln C_{o}
$$

where $C_{o}$ and $C$ are initial and final concentrations of total suspended and dissolved particles (TSDP), respectively. Firstorder reaction kinetics of EC process was evaluated for the removal efficiency of TSDP with respect to time, using (15).

Linear regression coefficient $\left(\mathrm{R}^{2}\right)$ was employed to ascertain the level of accuracy of fit of the kinetic model. Table 3 shows the kinetic parameters for first-order reaction obtained in this study. The $R^{2}$, reaction rate constant $(K)$, and the kinetic parameters $C_{o}$ and Care are presented in Table 3. These were obtained from the plot of LnC against time. The value of $\mathrm{K}$ was obtained from the slope of the plot. The results in Table 3 indicate that the highest $\mathrm{K}$ values were obtained at current densities of $0.5,2.0$, and $3.0 \mathrm{~A}$, while the least $\mathrm{K}$ value was obtained at $1.5 \mathrm{~A}$. The degree of fitting of the kinetic model as expressed in (4) was ascertained using linear regression coefficient $\left(\mathrm{R}^{2}\right)$. For both POME and PW, their $\mathrm{R}^{2}$ values as obtained from Figures 8 and 9, respectively, were more than 0.9 , hence, an indication that the first-order model fits the electrocoagulation experimental data satisfactorily,

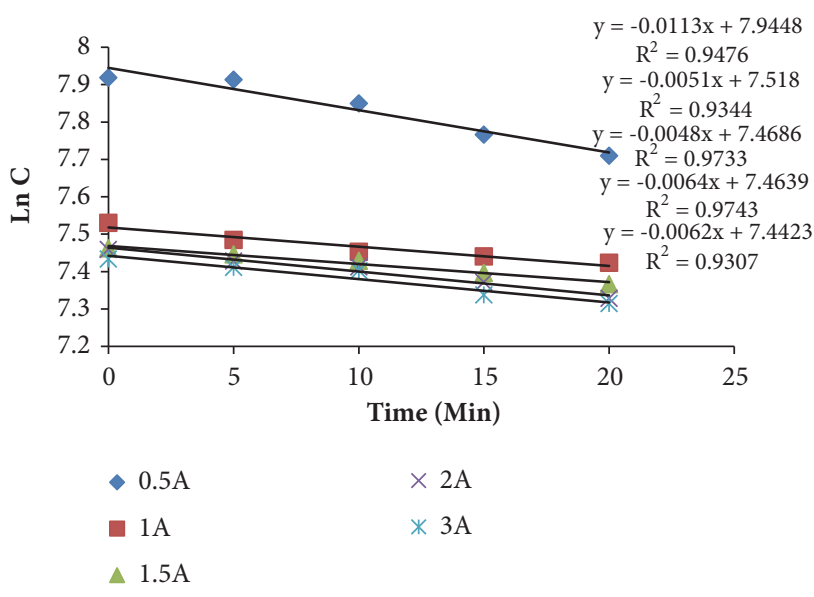

FIGURE 8: First-order kinetics for POME.

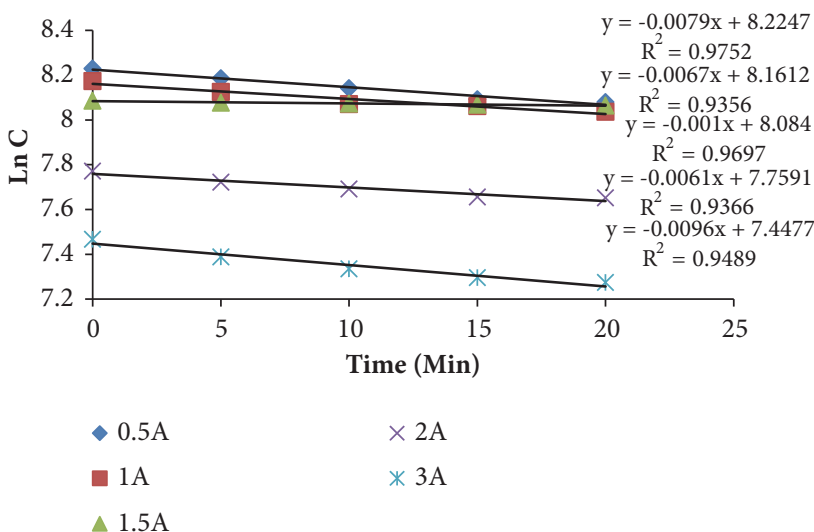

FIgURE 9: First-order kinetics for PW.

thus suggesting that the electrocoagulation of both POME and PW was perfectly described by first-order kinetic model.

3.3.2. Second-Order Kinetics. Equation (16) shows the second order kinetic equation for the electrocoagulation of the wastewaters studied.

$$
-\frac{\mathrm{dC}}{\mathrm{dt}}=-\mathrm{KC}^{-2}
$$

Equation (16) can be integrated to obtain

$$
-\frac{1}{\mathrm{C}}=\frac{1}{\mathrm{Co}}+\mathrm{Kt}
$$


TABLE 4: Second-order kinetic parameters for POME and PW.

\begin{tabular}{|c|c|c|c|c|c|c|}
\hline & \multicolumn{3}{|c|}{ POME } & \multicolumn{3}{|c|}{ PW } \\
\hline Current density (A) & Reaction constant (K) & $\mathrm{R}^{2}$ & 1/Co & Reaction constant (K) & $\mathrm{R}^{2}$ & $1 / \mathrm{Co}$ \\
\hline 0.5 & $4 \mathrm{E}-06$ & 0.9012 & 0.0004 & $1 \mathrm{E}-06$ & 0.7355 & 0.0003 \\
\hline 1.0 & $2 \mathrm{E}-06$ & 0.8938 & 0.0005 & $8 \mathrm{E}-07$ & 0.708 & 0.0003 \\
\hline 1.5 & $3 \mathrm{E}-06$ & 0.989 & 0.0006 & $1 \mathrm{E}-06$ & 0.9781 & 0.0003 \\
\hline 2.0 & $4 \mathrm{E}-06$ & 0.987 & 0.0006 & $2 \mathrm{E}-06$ & 0.7162 & 0.0004 \\
\hline 3.0 & $4 \mathrm{E}-06$ & 0.957 & 0.0006 & $5 \mathrm{E}-06$ & 0.8916 & 0.0006 \\
\hline
\end{tabular}

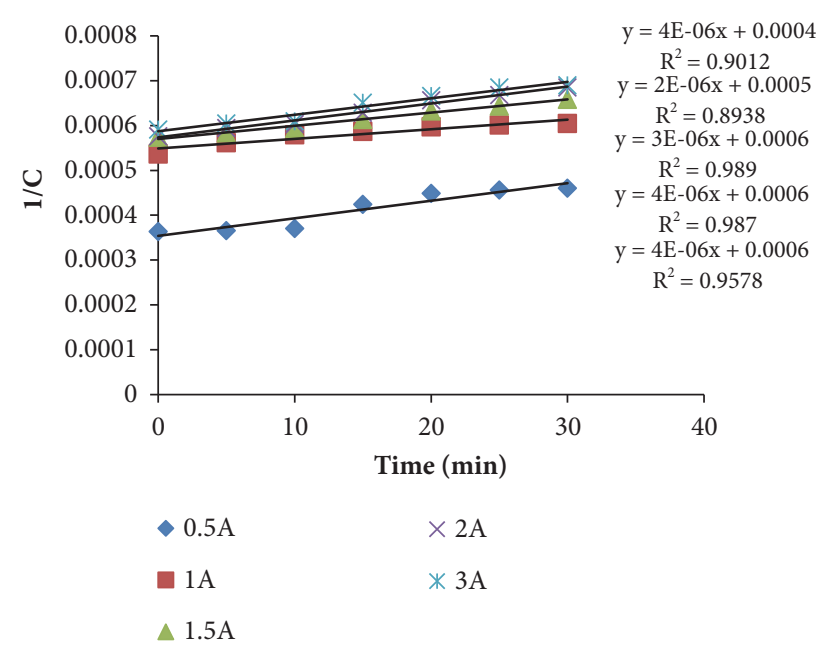

FIgure 10: Second-order kinetics for POME. where $C_{o}$ and $C$ are initial and final concentrations of total dissolved and suspended particles (TSDP), respectively. The second-order reaction kinetics of EC process was evaluated for the removal efficiency of TSDP with respect to time, using (17).

Tabulated in Table 4 are the second-order kinetics parameters for both POME and PW. A plot of $-1 / \mathrm{C}$ against time $(\mathrm{t})$ was used to obtain kinetics parameters $C_{o}$ and $\mathrm{K}$ as could be seen in Table 4. The $R^{2}$, reaction rate constant $(K)$, and the kinetic parameters $C_{o}$ and $\mathrm{K}$ are presented in Table 4.

Using linear regression coefficient $\left(\mathrm{R}^{2}\right)$ (Table 4$)$, the level of fitting of the kinetic model to the experimental data was determined. It was established that second-order kinetic model did not well describe the electrocoagulation of both POME and PW as evident in Figures 10 and 11. This was attributed to their low $\mathrm{R}^{2}$ values that were less than 0.9 .

\section{Conclusion}

Treatment of Palm Oil Mill Effluent and paint wastewater by electrocoagulation using iron electrodes has been found to be satisfactory. In the treatment of POME, the optimum removal efficiency of $65 \%$ was achieved under the following conditions: current density: $3 \mathrm{~A}$, temperature; $50^{\circ} \mathrm{C}$, time: $60 \mathrm{~min}$, and $\mathrm{pH}: 10$. A better removal efficiency was achieved in the treatment of $\mathrm{PW}$ as $76 \%$ at the following conditions: current density: $3 \mathrm{~A}$, temperature: $60^{\circ} \mathrm{C}$, time: $60 \mathrm{~min}$, and $\mathrm{pH}$ : 6. To achieve better removal efficiency, further study

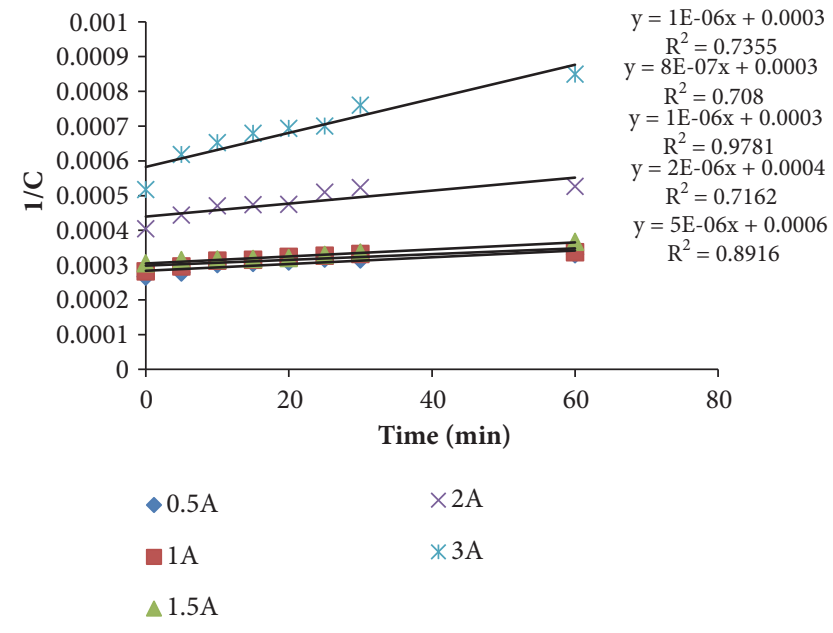

FIGURE 11: Second-order kinetics for PW.

on the optimization and thermodynamics of this process is encouraged. The result obtained from this study proves that this treatment method will be able to reduce the crudeness of POME and PW, making it more environmentally friendly. Hence it is hoped that palm oil mills and paint industries will treat their wastewaters using this treatment method, other than discharging them directly into the environment.

\section{Data Availability}

The experimental data used to support the findings of this study are included within the article.

\section{Conflicts of Interest}

The authors declare that they have no conflicts of interest.

\section{References}

[1] R. S. Elham, G. Akram, A. Saeid, D. Maryam, and N. Nasrin, "Removal of Reactive Red 141 Dye from Synthetic Wastewater by Electocoagulation Process: Investigation of Operational Parameters," Iranian Journal of Health, Safety and Environment, vol. 3, no. 1, 2016.

[2] C. R. O'melia, "Coagulation in Wastewater Treatment Plant Design," Ann Arbor Science, Ann Arbor, MiPress, London, 1978.

[3] O. A. Fadali, E. E. Ebrahiem, A. El-Gamil, and H. Altaher, "Investigation of the electrocoagulation treatment technique for 
the separation of oil from wastewater," Journal of Environmental Science and Technology, vol. 9, no. 1, pp. 62-74, 2016.

[4] A. Oikari, B. Lönn, M. Castrén et al., "Toxicological effects of dehydroabietic acid (DHAA) on the trout, Salmo gairdneri Richardson, in fresh water," Water Research, vol. 17, no. 1, pp. 81-89, 1983.

[5] A. H. El-Shazly and M. A. Daous, "Kinetics and performance of phosphate removal from hot industrial effluents using a continuous flow electrocoagulation reactor," International Journal of Electrochemical Science, vol. 8, no. 1, pp. 184-194, 2013.

[6] T. Tridib and R. D. Bhudeb, "Flocculation: A New Way to Treat the Waste Water," Journal of Physical Sciences, vol. 10, pp. 93-127, 2006.

[7] T. D. Reynolds and P. A. Richards, Unit Operation and Process in Environmental Engineering, Pws Publishing Company, Canada, 2nd edition, 1996.

[8] N. A. Norulaini, Z. Ahmad, A. I. Muhamad et al., "Chemical coagulation of setileable solid-free palm oil mill effluent (pome) for organic load reduction," Journal of Industrial Technology, vol. 10, no. 1, pp. 55-72, 2001.

[9] J. Vidal, L. Villegas, J. M. Peralta-Hernández, and R. Salazar González, "Removal of Acid Black 194 dye from water by electrocoagulation with aluminum anode," Journal of Environmental Science and Health, Part A: Toxic/Hazardous Substances and Environmental Engineering, vol. 51, no. 4, pp. 289-296, 2016.

[10] S. Muhammad, A. B. Alaadin, and N. A. Muhammad, "Electrocoagulation for the treatment of wastewater for reuse in irrigation and plantation," Journal of Basic and Applied Sciences, vol. 7, no. 1, pp. 11-20, 2011.

[11] A. N. Ghanim and S. K. Ajjam, "Modeling of textiles wastewater electrocoagulation via adsorption isotherm kinetics," Mechanical and Material Engineering, vol. 13, no. 1, p. 49, 2013.

[12] A. I. Adeogun and R. B. Balakrishnan, "Kinetics, isothermal and thermodynamics studies of electrocoagulation removal of basic dye rhodamine B from aqueous solution using steel electrodes," Applied Water Science, vol. 7, no. 4, pp. 1711-1723, 2017.

[13] S. Hariraj and K. M. Brijesh, "Assessment of kinetics behaviour of electrocoagulation process for the removal of suspended solids and metals from synthetic water," Environmental Engineering Research, 2016.

[14] C. Phalakornkule, J. Mangmeemak, K. Intrachod, and B. Nuntakumjorn, "Pretreatment of palm oil mill effluent by electrocoagulation and coagulation," ScienceAsia, vol. 36, no. 2, pp. 142-149, 2010.

[15] A. Akyol, "Treatment of paint manufacturing wastewater by electrocoagulation," Desalination, vol. 285, pp. 91-99, 2012.

[16] American Public Health Association, Standard Methods for Examination of Water and Waste Water, 1998.

[17] N. Saifuddin and S. Dinara, "Pretreatment Of Palm Oil Mill Effluent Using Magnetic Chitosan," Journal Of Chemistry, vol. 8, pp. 67-78, 2011.

[18] P. K. Holt, G. W. Barton, M. Wark, and C. A. Mitchell, "A quantitative comparison between chemical dosing and electrocoagulation," Colloids and Surfaces A: Physicochemical and Engineering Aspects, vol. 211, no. 2-3, pp. 233-248, 2002.

[19] M. A. Nasution, Z. Yaakob, E. Ali, S. M. Tasirin, and S. R. S. Abdullah, "Electrocoagulation of palm oil mill effluent as wastewater treatment and hydrogen production using electrode aluminum," Journal of Environmental Quality, vol. 40, no. 4, pp. 1332-1339, 2011.
[20] N. M. El-Sawy, H. H. Sokker, M. A. Hassan, and B. E. ElAnadouli, "Treatment of paint wastewater by radiation combined with coagulation and adsorption," International Journal of Environment and Waste Management, vol. 11, no. 1, pp. 87-99, 2013.

[21] M. Kobya, O. T. Can, and M. Bayramoglu, "Treatment of textile wastewaters by electrocoagulation using iron and aluminum electrodes," Journal of Hazardous Materials, vol. 100, no. 1-3, pp. 163-178, 2003.

[22] I. K. Shakir and B. I. Husein, "Lead removal from industrial wastewater by electrocoagulation process," Iraqi Journal of Chemical and Petroleum Engineering, vol. 10, no. 2, pp. 35-42, 2009.

[23] A. A. A. Nur and D. Zawawi, Electrocoagulation of Palm oil mill effluent using aluminum electrodes, vol. 3, Faculty of Civil and Environmental Engineering, University of Tun Hussein Onn Malaysia, 2012.

[24] H. Sonntag and K. Strenge, Coagulation Kinetics and Structure Formation, Deutscher Verlag der Wissenschaften, Berlin, Germany, 1987.

[25] M. A. Nasution, Z. Yaakob, E. Ali, S. M. Tasirin, and S. Abdullah, "Electrocoagulation of palm oil mill effluent as wastewater treatment and hydrogen production using electrode aluminum," Journal of Environmental Quality, vol. 40, no. 4, pp. 1332 1339, 2011. 

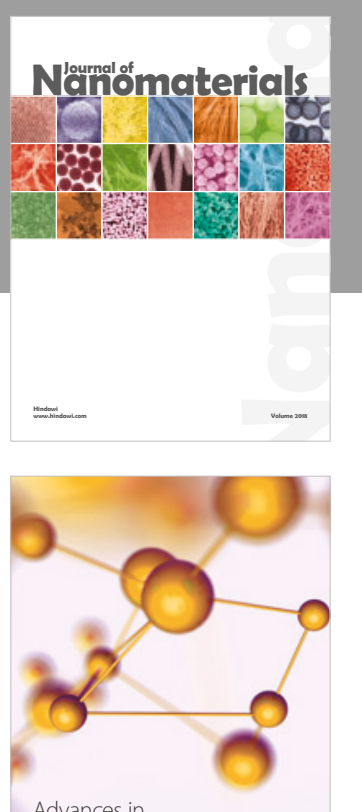

Physical Chemistry
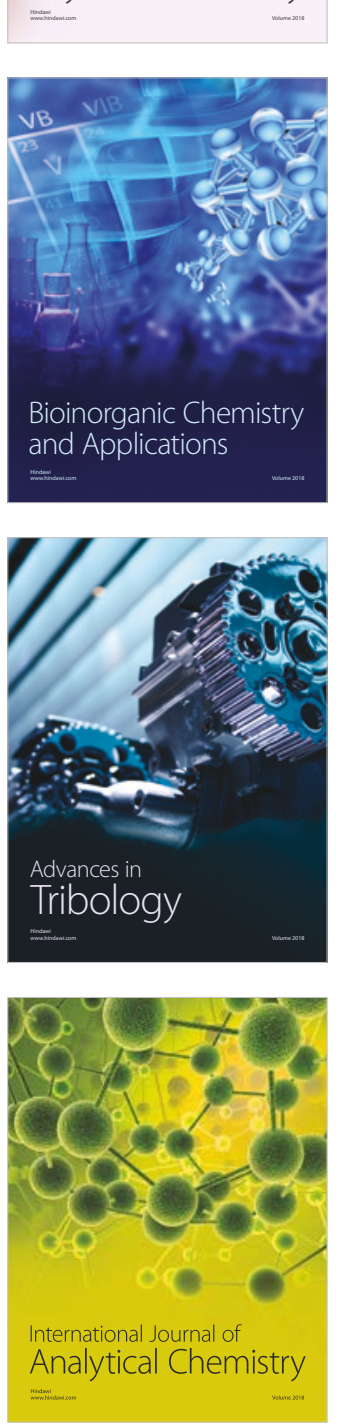

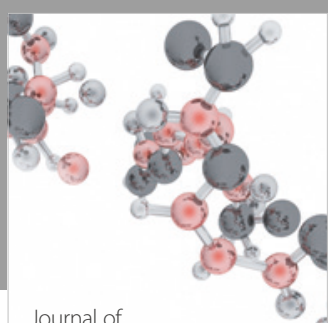

Analytical Methods

in Chemistry

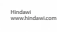

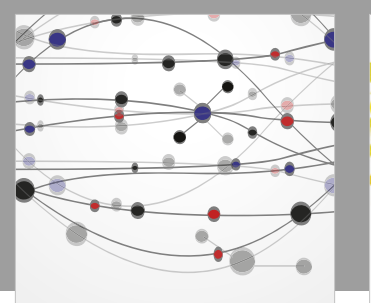

The Scientific World Journal

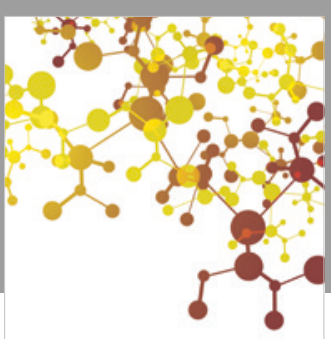

Journal of

Applied Chemistry
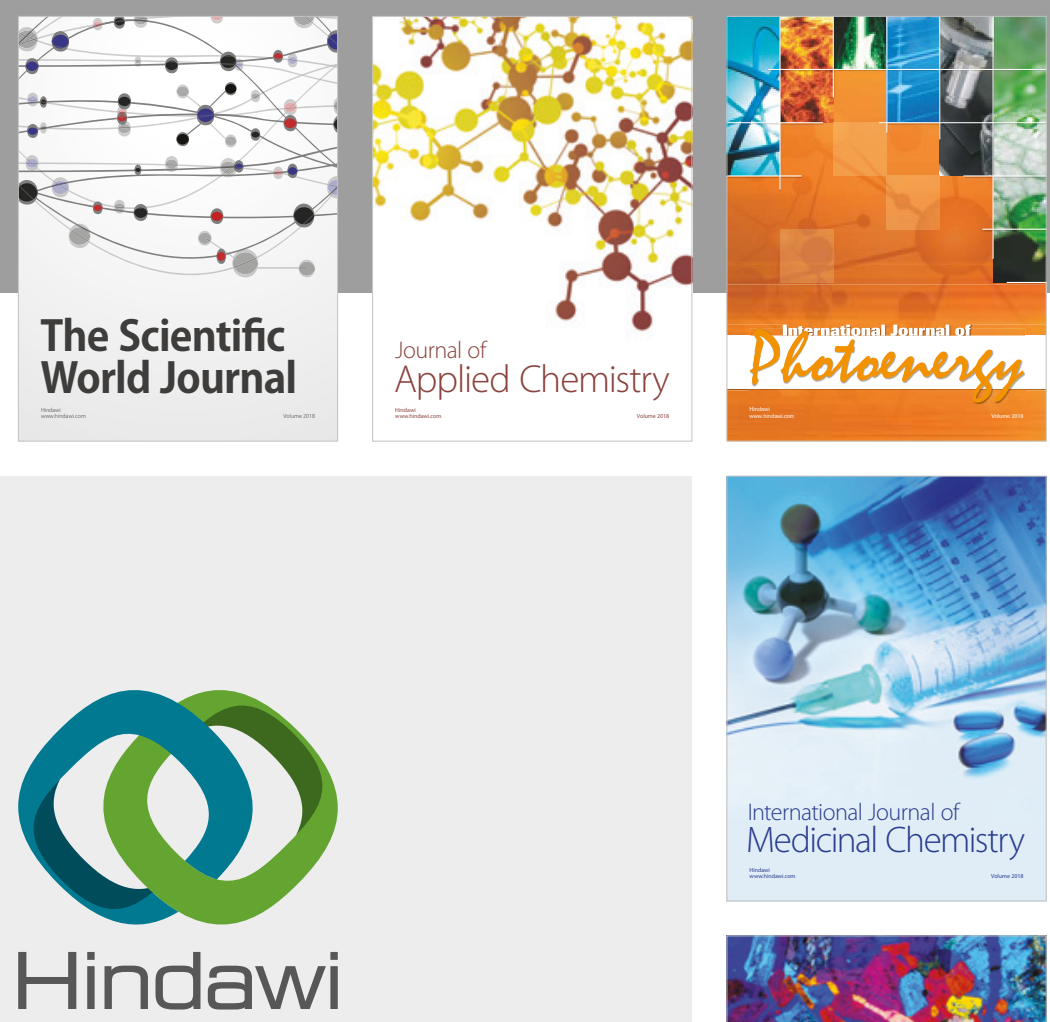

Submit your manuscripts at

www.hindawi.com

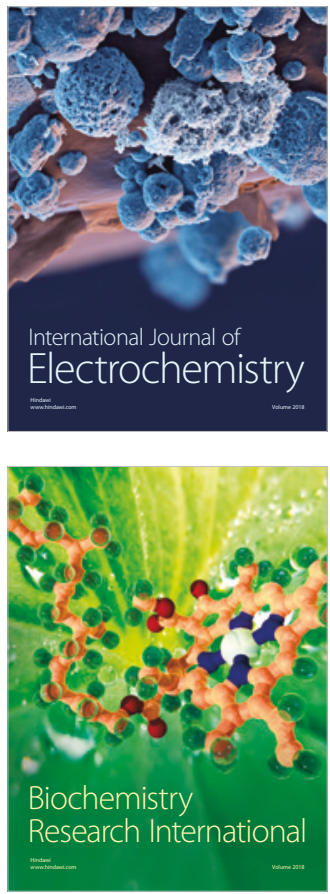